\title{
加熱延伸機を用いたシルク樹脂薄板の作製
}

\author{
于 偉東 ${ }^{* 1}$, 葛谷 俊博*2,\#, 平井 伸治*2, 玉田 靖*3
}

\section{Fabrication of Silk Resin Sheets Using a Hot-Rolling Equipment}

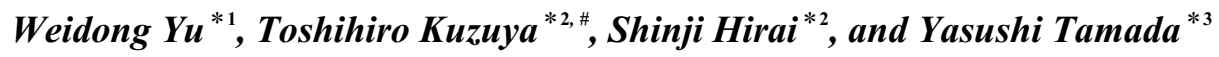 \\ ${ }^{* 1}$ Division of Engineering for Composite Functions, Muroran Institute of Technology, \\ 27-1, Mizumoto-cho, Muroran, Hokkaido 050-8585, Japan \\ ${ }^{* 2}$ College of Design and Manufacturing Technology, Muroran Institute of Technology, \\ 27-1, Mizumoto-cho, Muroran, Hokkaido 050-8585, Japan \\ ${ }^{*}$ Silk Materials Research Unit, National Institute of Agrobiological Sciences, \\ 1-2, Owashi, Tsukuba, Ibaraki 305-8634, Japan
}

\begin{abstract}
We attempted to fabricate silk resin sheets from silk powder using a hot-rolling equipment for continuous production. Silk powder was mixed with water, wrapped in a packaging material, and then passed through the nip between the heated rollers. Pulp sheet was suitable for the packaging material, while no resinification was observed using PETF sheet and aluminum foil as the packaging material. The resinification area increased with increasing temperature on the roll surface from $100{ }^{\circ} \mathrm{C}$ up to $150{ }^{\circ} \mathrm{C}$ under the condition of the water addition and rolling reduction ratio at $20 \mathrm{mass} \%$ and $70 \%$, respectively. The resinification area reached $90 \%$ at more than $60 \%$ of the rolling reduction ratio under the 20 mass $\%$ of water addition and $130{ }^{\circ} \mathrm{C}$ of the roll surface temperature. X-ray analysis showed that all the silk resin sheets consisted of silk II crystal structure. In addition, the broadening of FT-IR absorption peaks may be attributed to the formation of random-coil structure and Silk I. The bending strength of the silk resin sheet by the three-point bending test became lower with an increase in the rolling reduction ratio. The bending strength of the silk resin sheet exceeded $100 \mathrm{MPa}$ at $40 \%$ of the rolling reduction ratio, which was almost equivalent to that of the silk compact fabricated by pulse electric current sintering reported previously.
\end{abstract}

(Received 21 May, 2012; Accepted 11 June, 2012)

\section{1. 緒 言}

シルクは, 緎維以外にも粉末, フィルム, スポンジ形 状での用途が期待され, 細胞培養用基質 [1]，血液の抗凝 固剤[2]，ドラッグデリバリーシステムの担体[3]やスポ ンジ構造体による組織再生用の足場材料 [4]等の医療分野 での利用研究が進んでいる. また, シルク原料として, これまでサーマルリサイクルしか利用価值が見出されて いない裁断屑や使用済み繊維製品のような廃棄物が利用 されれば，樹脂や薄板の形でバイオマスプラスチックス としての用途展開も期待される. 例えば, フィブロイン タンパク質を主成分とするシルク粉末を加圧下で加熱す ると, ウミガメの一種であるタイマイの甲羅の筐甲に近 い色彩を有する半透明なシルク樹脂様成形体が得られる

\footnotetext{
\# corresponding author

$* 1 \quad$ 室蘭工業大学創成機能工学専攻

*2 室蘭工業大学もの創造系領域

*3 農業生物資源研究所
}

ことが既に報告 $[5]$ されている．具体的には，水分を含ま せたシルク粉末をホットプレスにより加圧下で加熱成形 すると, 半透明の成形体が得られ [6], 水分含有率 $27 \mathrm{mass} \%$ の原料から, 加圧力 $44 \mathrm{MPa}$, 加熱温度 $160^{\circ} \mathrm{C}$ で 1 分間保 持するホットプレス条件で作製すると70.6 MPa の曲げ強 度を有する成形体が得られることが報告されている。一 方, われわれも, ホットプレスの代わりにセラミックス や金属の焼結に用いられているパルス通電焼結装置を用 いてフィブロイン粉末に 20 mass $\%$ の水分を添加した原料 から, 所定の圧力下において所定温度まで $20^{\circ} \mathrm{C} / \mathrm{min} の 一$ 定速度で昇温し, 直ちに降温させる方法により均一性が 高い半透明化樹脂様成形体が作製されることを報告して いる $[7,8]$. 例えば, 加圧力を $20 \mathrm{MPa}$ 一定とした場合, $40^{\circ} \mathrm{C}$ 付近から成形物が半透明化し始め, $100{ }^{\circ} \mathrm{C}$ 以上において全 体が半透明化した樹脂様成形体が得られる.

シルクフィブロイン薄板についても, フィブロイン水 溶液からキャスト法により作製したフィブロインフィル ムを何層にも重ねた後, ホットプレスを用いて加熱加圧 することによる薄板の作製が報告 $[9,10]$ されている. フィ 
ブロイン水溶液にグリセリンを加えたものをガラス皿に キャストし, $40{ }^{\circ} \mathrm{C} て ゙ 1$ 日乾燥することによりフィブロイ ンフィルムを作製する. 水洗によりグリセリンを除去し たフィブロインフィルムを, フィブロイン水溶液をバイ ンダーとして何層にも積み上げた後, ホットプレスを用 い $19.6 \sim 29.4 \mathrm{MPa}$ の加圧下で $90{ }^{\circ} \mathrm{C} に$ 分加熱すること により積層構造を有する薄板が作製されている. 厚さ $2 \mathrm{~mm}$ の積層板では $117 \sim 186 \mathrm{MPa}$ に達する曲げ強度が報 告されている.

一方で，これらの手法はすべてバッチ式の作製方法で あり, バイオプラスチックとして利用するために, 安価 に量産するには適切なプロセスではない. そこで, 本研 究では, 連続的な成形方法により半透明化したシルクフィ ブロイン薄板を作製することを目的とした．現在までの 研究により, シルク粉末を原料とする半透明化した樹脂 様成形体を得るためには, 適切な水と熱と圧力が必要で あることが明らかとなっている，そこで，連続的な成形 方法として, 水を加えたシルクフィブロイン粉末を包み 材で包み, 回転する加熱された二つのロールの間を連続 的に通すことによりシルク薄板を連続的に作製する加熱 延伸法(以下, 連続ロール法)を試みた。半透明樹脂化に 及ぼすロール表面の温度, 圧下率, 水分添加量の延伸条 件の最適化を行うとともに, 得られた薄板の構造と物性 を評価した。

\section{2. 実験方法}

\section{1 シルク薄板の作製}

市販のシルク粉末 $(\mathrm{KB}$ セーレン, IM, 平均粒径 $7 \mu \mathrm{m})$ に全質量の〜30 mass\%となるように蒸留水を添加し, 乳 鉢を用いて十分に混合してスラリー状の含水シルク粉末 とした. 次に, $10 \mathrm{~g}$ のスラリー状粉末をPTFE シート(ニ チアス, 厚さ $: 0.3 \mathrm{~mm}$ ), アルミニウム箔(三菱アルミニウ ム, 厚さ : $0.011 \mathrm{~mm}$ )またはパルプシート (日本製紙クレシ ア, キムタオル, 厚さ : $0.008 \mathrm{~mm}$ )で包み, 続いて手動式 加熱延伸機 (井元作製所, IMC-1989 型, ロール寸法: $\phi 60$ $\times 132 \mathrm{~mm}$, ロール間距離: 〜 $3.0 \mathrm{~mm}$ )を用いて延伸させた。 最初に予備延伸によりスラリーの厚さを $1.5 \mathrm{~mm}$ に揃えた 後, 次に加熱延伸を行った.ロール表面の温度は 100 $\sim 160^{\circ} \mathrm{C}$, 最終圧下率は 30〜 70\%とした. 予備延伸と加熱 延伸におけるロール表面の温度は同一とした. 最終圧下 率は次式から求めた。

$$
\text { 圧下率 }=100 \times\left(h_{1}-h_{2}\right) / h_{1}
$$

ここで, $h_{1}$ は初期板厚 $(1.5 \mathrm{~mm}), h_{2}$ は延伸後の板厚を表 す.また, 圧力の測定は, 圧力測定フィルム (富士フィル ム, プレスケール・ッーシート(中圧用))を重ね, 常温下 の延伸を行った. 成形試料は $100^{\circ} \mathrm{C}, 0.05 \mathrm{MPa}$ の真空中 に3 日間保持する乾燥処理を行った後, デシケーター中
に保管した。

樹脂化の指標として，半透明領域の面積率を算出した. 面積率は, 目視により行い $5 \times 5 \mathrm{~mm}$ ブロック中で半透明化 したブロック数を全ブロック数で割り面積率とした. Fig. 1 に示すようにブロック中がほぼ半透明化している場合を 1 , ブロック中の 1 部の場合は 0.5 とした.

\section{2 三点曲げ試験}

三点曲げ試験は，電気機械式万能試験機(島津製作所製 EZ-test)を用い, 厚さ $0.4 \sim 0.8 \mathrm{~mm}$ の薄板から延伸方向に 向かって長さ $12 \mathrm{~mm}$, その垂直方向に向かって幅 $3 \mathrm{~mm}$ の JIS 規格外の小型板状試料を切り出し, 支点間隔 $10 \mathrm{~mm}$, 試験速度 $0.5 \mathrm{~mm} / \mathrm{min}$ の試験条件で加重を加えて破断させ, 最大荷重を求めた. 圧子は, 先端曲率半径 $r=2 \mathrm{~mm}$, 長さ $40 \mathrm{~mm}$ の半円柱状のものを用いた. 測定は 3 回行い, そ の最大荷重の平均值から三点曲げ強度を算出した。 また, 応力一歪み曲線から曲げ弾性率を算出した.

\section{3 構造解析}

XRD(リガク, RINT-2100-Ultima+), FT-IR(日本分光, FT/IR-430)により, 成形体の構造をシルク粉末の解析結果 と比較した。 XRD は $\mathrm{Cu}-\mathrm{K} \alpha$ 線を用い, 管球条件は $40 \mathrm{kV}$, $40 \mathrm{~mA}$ とした. FT-IRは, 薄板を粉砕後, メノウ乳鉢です り潰した粉末を用いた KBr 法により測定した。また, 薄 板の破断面について低真空機能を内蔵した SEM(日本電子, JSM-6610LV)を用いた観察を行った.

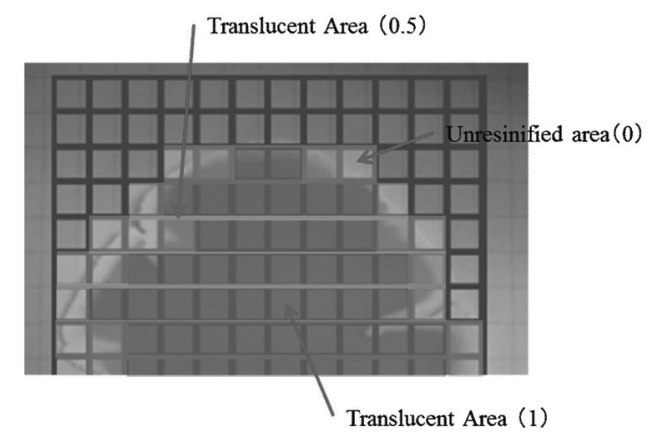

Fig. 1 Definition of area ratio on translucent region for the silk resin sheets.

\section{3. 結果および考察}

Fig. 2 にロールと材料との間に作用する力の関係 [9]を 示す. 1 パス当たりの圧下率は, 試料がロールに引き込ま れる際のかみ込み角 $(\alpha)$ にって決定される。いま, ロー ルの入口について考えると, ロール中心力 $\left(P_{\mathrm{R}}\right)$ の作用に より, ロールの回転とともにロールの接線方向に摩擦力 $(F)$ が働き(式 $(2))$, 試料がロールにかみ込まれる. 試料 が押し戻されないためには，(摩擦力の水平成分 $(F \cos \alpha)$ がロール中心力 $\left(P_{\mathrm{R}}\right)$ の水平成分 $\left(P_{\mathrm{R}} \sin \alpha\right)$ よりも大きくな る必要がある. ロールは縦型であるので試料自重 $m g$ と外 力 $F$ 'を考慮し (3)の関係式が導かれる. したがって, $\alpha$ と ロールと試料間の摩擦係数 $(\mu)$, 試料の自重 $m g$ および外 
カ $F$ 'の間に(4)式が成り立つ.

$$
F=\mu P_{R}
$$

$$
F \cos \alpha+m g+F^{\prime}>P_{R} \sin \alpha
$$

$\mu+\left(m g+F^{\prime}\right) /\left(P_{R} \cos \alpha\right)>\tan \alpha$

式(4)より, 摩擦係数が大きいほどかみ込み角 $(\alpha)$ が大き くなる. そこで, 摩擦係数が $0.08 \sim 0.12$ (PTFE/鋼) の PTFE シート， 0.40 (アルミ/鋼)のアルミニウム簿，０.50〜0.65の パルプシートをシルク粉末の包み材に用いて延伸した.

Fig. 3 にそれぞれの包み材を用いた場合の延伸後の試料の 外観を示した．なお，水分添加量は 20 mass\%，圧下率は $70 \%$ ，ロール表面温度は $130^{\circ} \mathrm{C}$ 一定とした。 PTFE シート では殆どかみ込みが起らないためシルク粉末の加熱溶融 による半透明化は見られず，アルミニウム䇴では部分的 な半透明化が確認された，一方，パルプシートでは外周 部を除いて半透明化した。半透明化した部分の面積率は, PTFE シート，アルミニゥム箔，パルプシートの順に $4 \%$, 7\%，97\%となり，クリティカルに増大することがわかる. 摩擦係数の閾值は圧延前の厚さ $h_{1}$ 㧍よび圧延後の厚さ $h_{2}$, ロール径 R により次のように表すことが出来る [9].

$$
\mu>\tan \alpha-\frac{m g+F}{P_{R} \cos \alpha} \cong \frac{\sqrt{R\left(h_{1}-h_{2}\right)}}{R-0.5\left(h_{1}-h_{2}\right)}-\frac{m g+F}{P_{R} \cos \alpha}
$$

自重と外力を 0 とすると圧下率 $70 \%$ の場合，（5)式の右 辺は 0.19 となり, PTFE シートを用いた場合, 外力を加え ないと PTFE と鋼製ロール間に滑りが発生し圧延が出来な いことがわかる，一方で，アルミニウム簿の場合は，鋼 製ロールとアルミ箔の間には十分な摩擦が働くと推定さ れる. 実際, PTFE シートを用いた場合, 圧延するために 外力を加える必要があった，しかしながら， PTFE，アル ミ䇴ともに圧延にかかわらず半透明化しないのは, シル ク粉末と包み材間の摩擦が小さいため, シルク粉末がう まくかみ込まれないためと考元られる，以後の実験はパ ルプシートを包み材に, 外力 $F^{\prime}=0$ として実験を行った.

次に，パルプシートを包み材に用いた場合のロール表 面の温度, 圧下率, 水分添加量が半透明化に及ぼす影響 について調べた. Fig.4 は, 薄板の半透明化に及ぼすロー ル表面温度の影響を示す. 水分添加量は $20 \mathrm{mass} \%$, 圧下 率は 70\%一定とした。半透明化の面積率は $100^{\circ} \mathrm{C}$ の場合 を除いて $90 \%$ 以上に達し， $130^{\circ} \mathrm{C}$ までは温度の上昇と共に

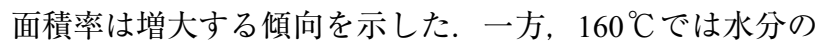
沸騰による多数の気泡が確認された。 このような発泡痕 は，ホットプレスにより，水分を $30 \mathrm{mass} \%$ \%添加した 場合において成形温度にかかわらず確認されている[6].

Fig. 5 は, ロール表面温度が $130^{\circ} \mathrm{C}$ の場合の薄板の半透明 化に及ぼす圧下率の影響を示す。なお，水分添加量は $20 \mathrm{mass} \%$ 一定とした．同時にそれぞれの圧下率における
試料に負荷される圧力を見積もるため圧力測定フィルム (プレスケール)を重ねた延伸を常温にて行った結果を併 記した(Fig. 6). 圧下率の増加とともに半透明化した部分 の面積は増加し，60\%以上においてその面積率は約 $97 \%$ に達した。また，プレスケールで見積もられる最大圧力 值は，圧下率が 30，40，50，60，70\%と増加するに従い $14 ， 18 ， 23 ， 25 ， 28 \mathrm{MPa}$ と増加する傾向が見られた。 こ れまで，パルス通電焼結装置を用いた成形体の作製 [7,8] で, 加圧力を $20 \mathrm{MPa}$ 一定とした場合, $40^{\circ} \mathrm{C}$ 付近から成形 物の半透明化が始まっていることから, 本連続ロール法 に拀いても圧下率が 50 ～70\%で十分な圧力が負荷されて いることがわかる，さらに，ロール表面温度を $130^{\circ} \mathrm{C}$, 圧下率を $70 \%$ でそれぞれ一定とした場合, 半透明化に及 ぼす水分添加量の影響を Fig. 7 に示す. $20 \mathrm{mass} \%$ \%では, 水分添加量の増加とともに半透明化した部分の面積率が 増大したものの, その後は減少に転じた. 使用したシル ク粉末は元々水分を含有するが, ホットプレスやパルス 通電燒結装置を用いた成形ではさらにそれぞれ $27 \mathrm{mass} \%$ [6]，20mass\%[7,8]まで水分を添加していた．蒸留水の添 加はシルク粉末の流動性を上げるため, $25 \mathrm{mass} \%$ 以上で は十分な加圧力が得られなかったと考えられる.さらに， 過剩な水分が揮発することでシルク粉末の温度が $100^{\circ} \mathrm{C}$ 以上には上がらず, シルク粉末が残存したものと推定さ れる。

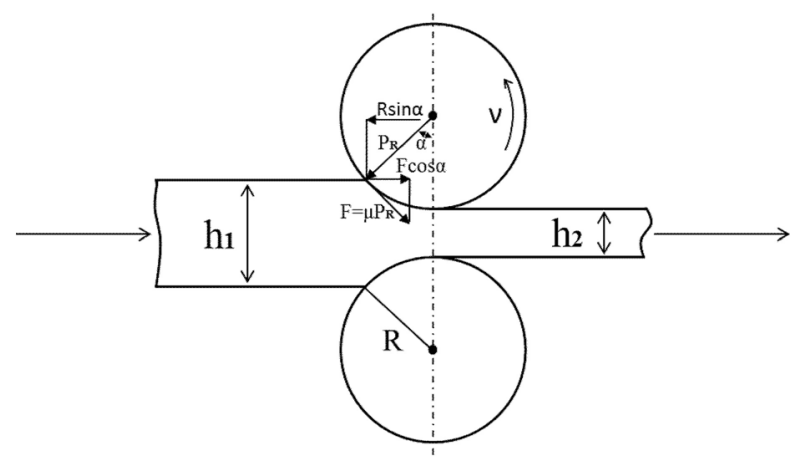

Fig. 2 Schematic illustration of a Hot-Rolling equipment[9].

次に, 水分添加量を 20 mass \%, 圧下率を $70 \%$ 一定とし, ロール表面の温度が $130{ }^{\circ} \mathrm{C}$ で延伸した薄板を用い, 乾燥 処理中の質量変化を測定した結果を Fig. 8 に示す。質量の 減少は乾燥時間が 24 時間以降は緩やかになり, また 72 時間以降は殆ど見られなくなった。

シルク薄板の破断面および研磨後断面の SEM 観察結果 を Fig.9に示す.シルク破断面は圧下率の増大と共に荒く なる傾向が見られた．また研磨した断面を観察すると圧 下率の増大と共にクラックの増大が観察された. 圧下率 $70 \%$ 場合, 表面近傍にクラックが存在し, その向きは 圧力軸に対して垂直であった. クラックの向きがそろっ ていることから，クラックは空孔が押しつぶされたまた は剪断応力の増加により発生したものと推察できる. 後 
者の場合, 中心部にクラックが発生しないという観察結 果をよく説明することが出来る.

Fig. 10 は出発原料のシルク粉末と Fig. 5 の薄板の XRD パターンを示す. 圧延前後においてシルク II $(2 \theta=9.1,18.9$, $\left.20.7^{\circ}\right)$ が同定された。 また圧下率の増加とともに低角側に 回折ピークがシフトした. シルク I (110)に対応する回折 ピークが $2 \theta=19.7^{\circ}$ に存在するため, シルク I の割合が増 加している可能性がある [9]. シルク成型体のガラス転移 温度は水分量の増加とともに低くなり, 24 時間真空乾燥 した場合でも，ガラス転位温度は $120^{\circ} \mathrm{C}$ 程度であった $[8]$.
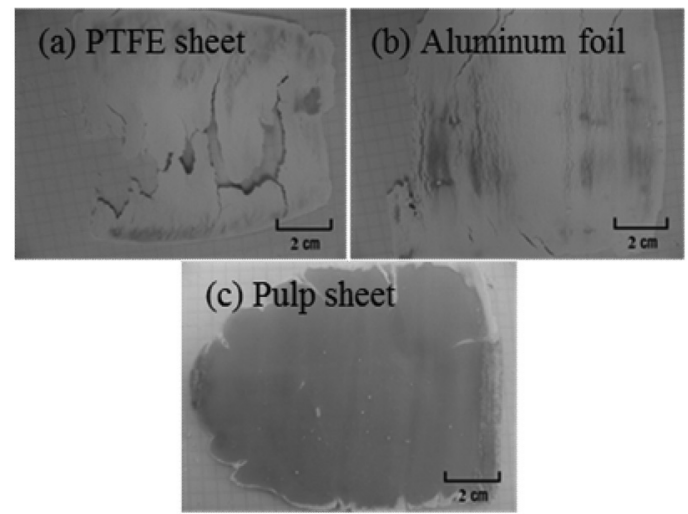

Fig. 3 Effect of the wrapping materials upon the morphology of silk sheet. Rolling reduction ratio : $70 \%$, Roll temperature : $130{ }^{\circ} \mathrm{C}$, Water addition : 20 mass $\%$.
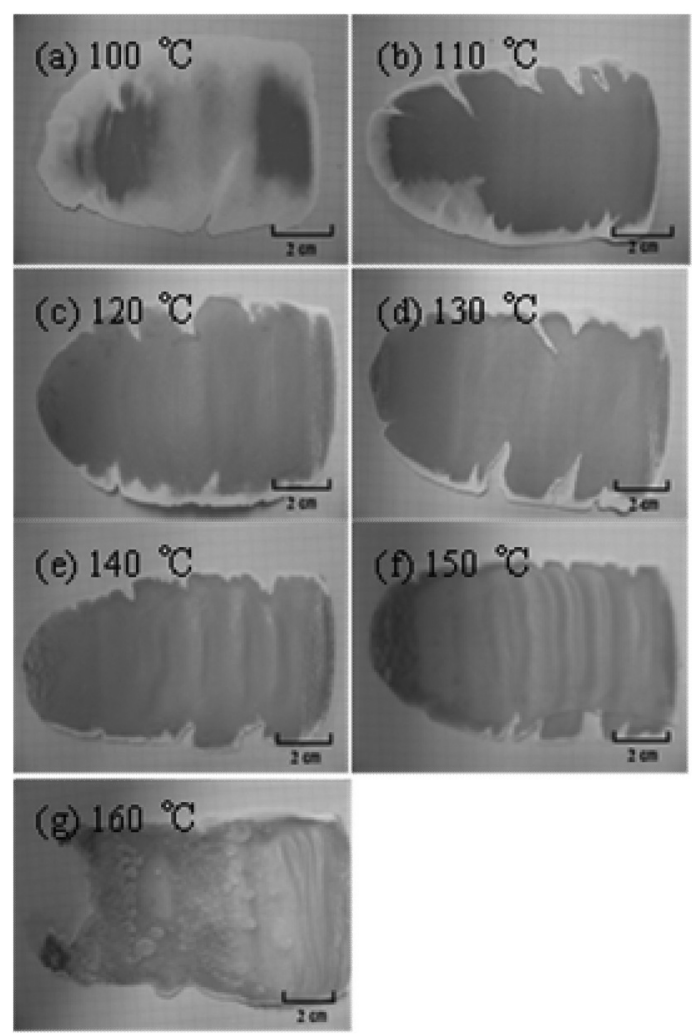

Fig. 4 Effect of the roll temperatures upon the morphology of silk sheets. Rolling reduction ratio : $70 \%$, Water addition : 20 mass $\%$.
圧延温度は $130{ }^{\circ} \mathrm{C}$ であるため, 一旦アモルファス化した 後, 新たな結晶相が生じたのではないかと考えられる.

出発原料のシルク粉末と Fig. 5 の薄板の FT-IR スペクト ルを Fig. 11 に示す。圧下率によらずシルクフィブロイン に典型的な Amid I, Amid II および Amid III の吸収バンド が確認できる。この吸収バンドはフィブロインタンパク のコンフォメーションによりシフトすることが知られて おり, ランダムコイル構造では $1650 \mathrm{~cm}^{-1}(\mathrm{Amid} \mathrm{I})$ と $1235 \mathrm{~cm}^{-1}$ (Amid III) 付近の吸収が, シルク I 構造では 1647

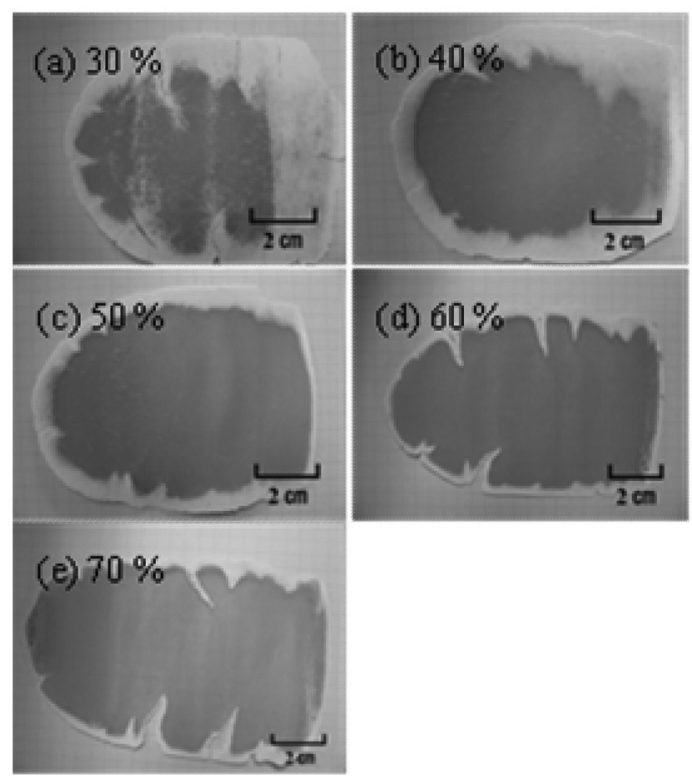

Fig. 5 Effect of the rolling reduction ratio upon the morphology of a silk sheet. Rolling temperature : $130{ }^{\circ} \mathrm{C}$, Water addition : 20 mass $\%$.
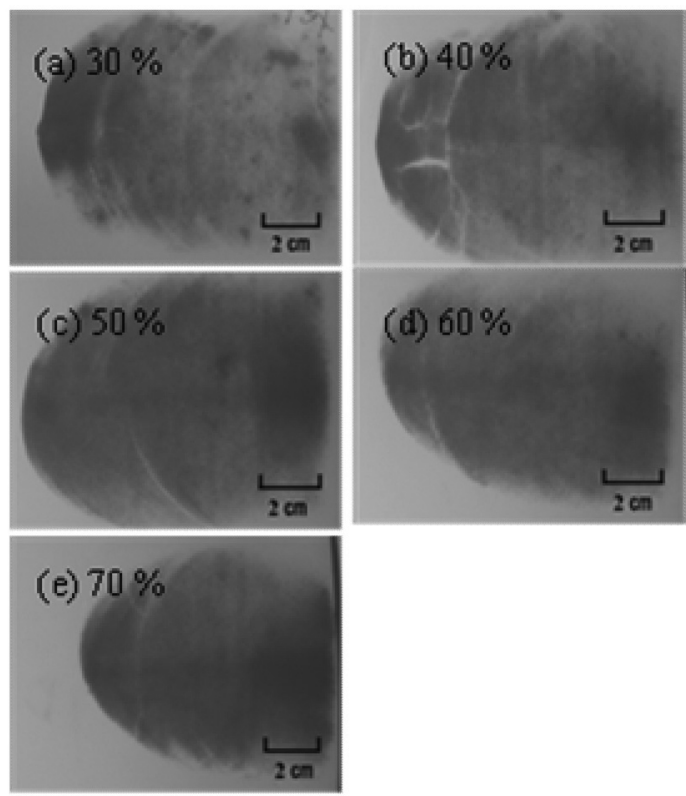

Fig. 6 Effect of the rolling reduction ratio upon the pressure distribution. Roll temperature : room temperature, Water addition : 20 mass\%. Red color comes from the pressure indicate sheet $\left(\right.$ PRESCALE $^{\mathrm{TM}}$ ) for measurement of pressure. 


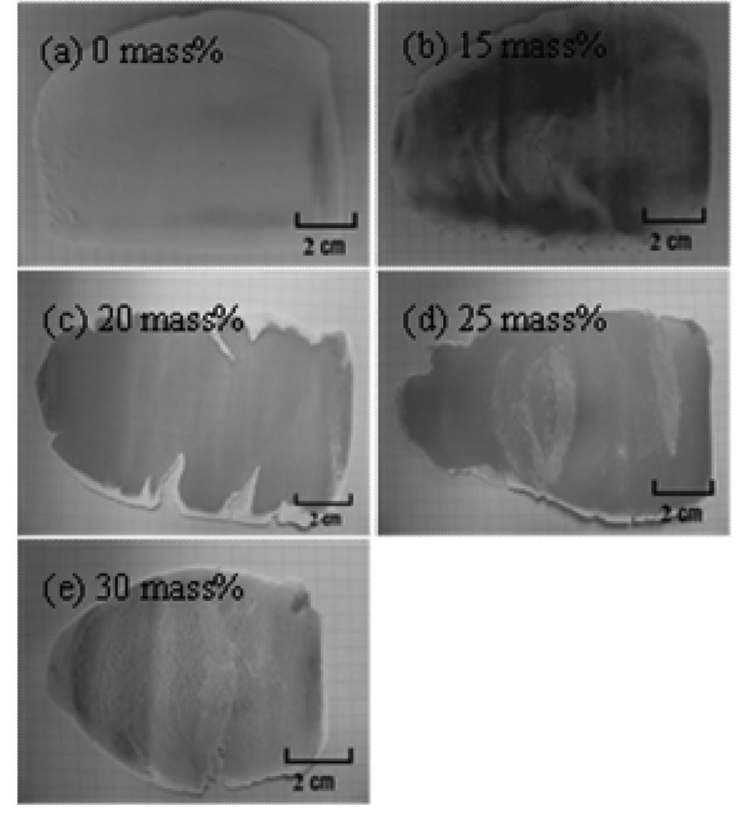

Fig. 7 Effect of the additive amount of water upon the morphology of silk sheets. Rolling reduction ratio : $70 \%$, Roll temperature : $130{ }^{\circ} \mathrm{C}$.

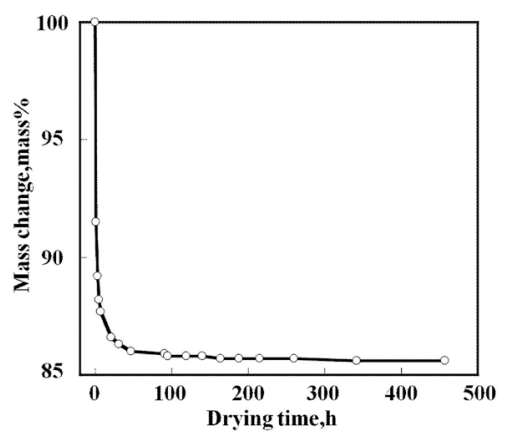

Fig. 8 Time variation of mass of silk sheet. Rolling reduction ratio: $70 \%$, Drying temperature : $100{ }^{\circ} \mathrm{C}$, Drying pressure : $0.05 \mathrm{MPa}$.

〜 $1657 \mathrm{~cm}^{-1}$ および $1539 \mathrm{~cm}^{-1}$ 付近に吸収バンドを持つと報 告されている。 また, $\beta$ シート構造では $1630 \mathrm{~cm}^{-1}($ Amid I), $1265 \mathrm{~cm}^{-1}$ (Amid III), $700 \mathrm{~cm}^{-1}$ (Amid V) 付近に吸収バンド が存在する $[9,10]$. 圧延後の FT-IR スペクトルは圧延前の シルク粉末に比べ高波数側にブロードニングするのが確 認できる. このため, 圧延により Silk I またはランダムコ イル構造の割合が増加している可能性が考えられる. パ ルス通電焼結装置を用いた樹脂様成形体においても，類 似したスペクトルが観察されている。 なお，形成機序や 結晶相の詳細な同定については, 今後の課題として検討 を進める予定である。

Fig. 12 は三点曲げ強度と曲げ弾性率の圧下率依存性を 示す。三点曲げ強度は, 圧下率の増加とともに減少傾向 を示した. Fig.9からは圧下率の増加とともに断面のク ラックの数が増大することが確認されているが, 圧延中 に急激な加熱により発泡が起こり易くなった結果, 残っ た空孔がクラックとなり破断強度が低下したものと考え られる。なお，圧下率が $40 \%$ の場合における曲げ強度は
$100 \mathrm{MPa}$ を超えているが, この值はフィブロインフィルム を積み上げた積層構造を有する薄板の 117〜 186 MPa には 劣るものの, パルス通電焼結装置を用いて作製した成形 体のそれとほほ同じであった. ところで，今回作製した 薄板の最大三点曲げ強度は沉用エポキシ樹脂の 77〜 $135 \mathrm{MPa}[12]$ と同等以上であり, また, ポリ乳酸の $57 \mathrm{MPa}$ [13］を大きく超える值となった．また，曲げ弾性率にお いても, 沉用エポキシ樹脂の $2.4 \sim 3.4 \mathrm{GPa}$, ポリ乳酸の $2.2 \mathrm{GPa}[14]$ を超えることが確認された.

\section{4. まとめ}

加熱された二つの回転ロールの間に水を加えたシルク 粉末を包み材ではさんで通す方法(連続ロール法)により， 半透明なシルク薄板の作製を検討した.

(1) 水分添加量を $20 \mathrm{mass} \%$, 圧下率を $70 \%$, ロールの表 面温度を $130^{\circ} \mathrm{C}$ 一定とした場合, ロールと包み材との間 の摩擦係数 $(\mu)$ の間值は 0.19 以上であると見積もられた. 従って, 鋼ロール間の摩擦係数が 0.12 である PTFEを包 み材として使用した場合, 包み材がロール間へかみ込め

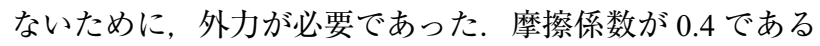
アルミ箔を包み材とした場合も半透明樹脂化は起こらず 粉末状であったが, これは, 包み材とシルク粉体間の摩 擦係数が小さいため, シルク粉末が十分に加圧・加熱さ れる程にロールへのかみ込みが起こらなかったと考えら れる. パルプシートを包み材として利用した場合, 連続 ロール法による樹脂化に成功した.この条件においてロー ル表面温度のみを变化させたところ $100^{\circ} \mathrm{C}$ から半透明化

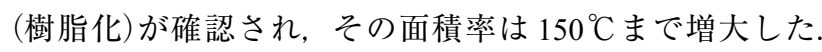
水分添加量を $20 \mathrm{mass} \%$, ロールの表面温度を $130{ }^{\circ} \mathrm{C}$ 一定 とし，圧下率のみを変化させたところ，60\%以上におい て半透明化面積率は $90 \%$ に達した。ロール表面温度を $130{ }^{\circ} \mathrm{C}$, 圧下率を $70 \%$ 一定として, 水分添加量のみを変化

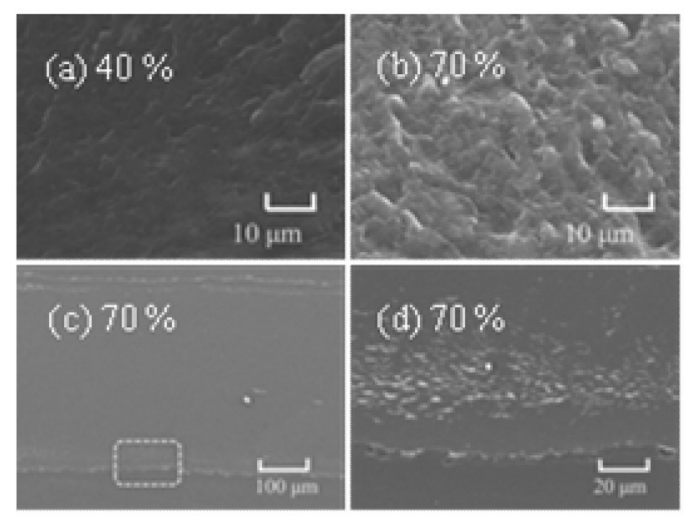

Fig. 9 SEM observations of cross sections by fractures of silk sheets obtained with various rolling reduction ratios. Before polishing (a) and (b), after polishing (c) and (d). Micrograph (d) presents the magnified photo at the indicated area by dotted box in (c). 


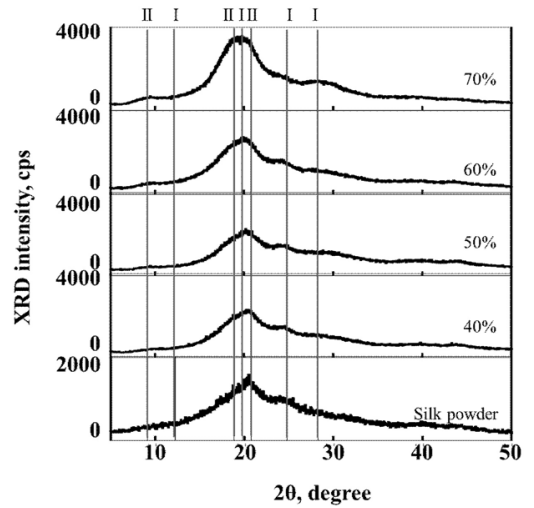

Fig. 10 XRD patterns of silk sheets obtained under various rolling reduction ratios. Rolling temperature: $130{ }^{\circ} \mathrm{C}$, Water addition: 20 mass\%, Wrapping material : Pulp sheet.

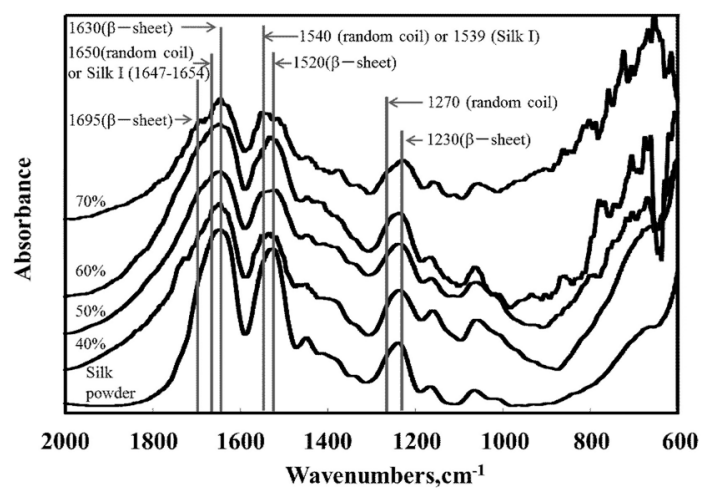

Fig. 11 FT-IR spectra of silk sheets obtained under various rolling reduction ratios. Rolling temperature : $130{ }^{\circ} \mathrm{C}$, Water addition: 20 mass\%, Wrapping material : Pulp sheet.

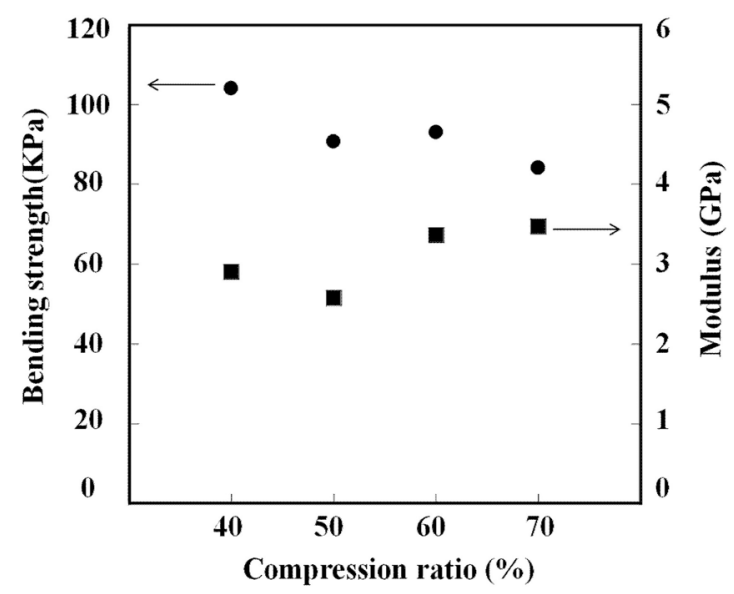

Fig. 12 Bending strengths and modulus of silk sheets obtained under various rolling reduction ratios. Rolling temperature : $130{ }^{\circ} \mathrm{C}$, Water addition : 20 mass\%, Wrapping material : Pulp sheet.
させたところ， $20 \mathrm{mass} \%$ \%では半透明化面積率が増大し たものの, その後は減少に転じた。

(2) 薄板の破断面の SEM 観察から, クラックの形成が確 認され，その数は圧下率とともに増加する傾向を示した。

(3) 圧延後の薄板の XRD および FT-IR スペクトルからは, 圧延前のシルク粉末と同様にシルク II が同定された。 ま た, 圧下率の増大とともにXRDのピークは低角側にシフ トし，FT-IR スペクトルはブロードニングする傾向が見ら れた。これは，ランダムコイルまたはシルク Iへの転移に 起因すると考えられる.

(4) 三点曲げ試験による曲げ強度は, 圧下率の増加ととも に減少する傾向が確認された。しかし, 圧下率が $40 \%$ の 曲げ強度は $100 \mathrm{MPa}$ を超え, フィブロインフィルムを積 み上げた積層構造を有する薄板には劣るものの, パルス 通電焼結装置を用いて作製した成形体のそれとほぼ同じ であった。

よって, 本研究により検討した連続ロール法により, シルク粉末から連続的にシルク樹脂薄板の生産が可能で あることが示唆され，バイオプラスチックとしてのシル ク樹脂の利用が期待出来る.

\section{文 献}

1. Y. Gotoh and Y. Tamada, J. Insect Biotech. Sericol., 74, 39 (2005).

2. Y. Tamada, Biomaterials, 25, 377 (2004).

3. T. Hanawa, A. Watanabe, T. Tsuchiya, R. Ikoma, M. Hidaka and M. Sugihara, M. Chem. Pharm. Bull., 43, 284 (1995).

4. Y. Tamada, Biomacromolecules, 6, 3100 (2005).

5. K. Komatsu, in "Insect utilization science series, Invitation to silk”, Science House, Tokyo, 254 (1997).

6. J. Hosokawa, T. Endo, M. Nishiyama, S. Mori and M. Funahashi, Kobunshi Ronbunshu, 50, 929 (1993).

7. S.Hirai, A.Kaneko and Y.Tamada, Bio Industry, 24, 27 (2007).

8. A.Kaneko, Y.Tamada, S.Hirai, T.Kuzuya and T. Hashimoto, Macromole.Mater.Eng., 297, 272 (2012).

9. Q. Lu, X. Hu, X. Wang, J. A. Kluge, S. Lu, P. Cebe and D. L. Kaplan, Acta Biomaterialia, 6, 1380 (2010).

10. D. K. Kim, T. Itoh and T. Konishi, Sen'i Gakkaishi, 53, 365 (1997).

11. J. Hosokawa, T. Endo, R. Kitagawa,M. Nishiyama, S. Mori, A. Sakoguchi and R. Ueoka, J. Chem. Eng. Jpn., 29,1057 (1996).

12. Jpn. Kokai Tokkyo Koho, H6-155653.

13. The Society of Polymer Science, "Koubunshi data handbook-Ouyouhen-“, Baifukan, Tokyo, p.116(1986).

14. Seibunkaisei-Purasuchikku-Kenkyuukai-Hen, "SeibunkaiseiPurasuchikku Handbook", N • T • S, Tokyo, p.282(1995). 